\title{
Editorial
}

\section{Decolonising global constitutionalism}

J O N A T H A H A V E R C O F T, J A C O B E I S L E R, J O S H A W, A N T E WIENER a n d A L N A O LEON

Beginning in 2020 the journal's editorial offices will be based at the University of Southampton in England. As a port city Southampton is probably most famous for two transatlantic crossings that departed from her harbour - the R.M.S. Titanic which sailed in 1912, and the departures of the Speedwell and the Mayflower in 1620. While the Titanic is probably the more famous sailing - having been immortalised in song and film - the sailings of the Speedwell and Mayflower from Southampton harbour precisely 400 years ago are certainly more significant for the history of global constitutionalism.

Today the Mayflower sailing is remembered as the event that began the European colonisation of North America. It is either retold as a story of pious Puritans fleeing religious persecution in Europe, who went to the Americans hoping to establish a new way of life, and who are celebrated each year through the American holiday of Thanksgiving, or as the moment that began the European colonisation of the Americas, the seizure of Indigenous land, and a process of genocide in the Americas that saw a 90 per cent reduction in the Indigenous population of the Americas between first contact in 1492 to $1650 . .^{1}$ There are truths in both of these narratives. The Puritan settlers had faced persecution for practising their form of Christianity in England in the early 1600s and had first fled to Holland before deciding to enter into a contract with the Virginia company to settle in the Americas. However, of the 102 settlers on the Mayflower voyage only 28 of the adults were members of the Puritan congregation, while almost half of the settlers were not Puritans, but passengers who had been recruited by the company sponsoring the voyage. ${ }^{2}$ The motivations for the endeavour were a

${ }^{1}$ LA Newson, 'The Demographic Collapse of Native Peoples of the Americas, 1492-1650' in 81 Proceedings of the British Academy (Oxford University Press, Oxford, 1993) 277.

2 N Philbrick, Mayflower: A Story of Courage, Community, and War (Penguin, New York, NY, 2006) 25. 
mixture of a desire for religious freedom and hope that the new colony would be profitable for the London-based financial backers who expected the colonists to do seven years of labour for the investors in exchange for receiving patent for the colonial land. From the perspective of the Indigenous peoples inhabiting the East Coast the arrival of the colonists was not significant at first. European fisherman had been trading with the Indigenous people along the Eastern seaboard for nearly a century. Previous European visitors had captured and enslaved some of the Indigenous peoples they had found along the East Coast. And some of these Indigenous slaves had travelled to Europe, learned English, returned to the Americas, escaped, and shared their knowledge of Europe with Indigenous nations living along the east coast. In the years prior to the arrival of the Mayflower bubonic plague had been introduced by European fishers to the Indigenous communities on the east coast of the Americas wiping out several villages prior to the arrival of the Mayflower settlers. In the early days of their settlement the Mayflower colonists were able to reach accommodation with the nearby Wampanoag and their Sachem Massasoit. Yet in the subsequent generations the accord between the settlers and the Massasoit broke down, with two wars - the Pequot War of 1637 and King Philip's War of 1675 - the massacres of the Indigenous populations by European colonists, and the enslavement and forced expulsion of many surviving Indigenous peoples. Within 60 years the Indigenous population around the original Plymouth Colony had been almost completely obliterated through a combination of disease, warfare, massacre, and slavery, paving the way for a rapid expansion of English colonisation of the Eastern seaboard.

While a significant portion of this colonial practice was driven by pestilence and violence, it was enabled at every turn by a legal process. Three legal agreements in particular made the Mayflower colony possible. The first, and most famous, is the Mayflower Compact. The Mayflower had originally intended to settle in the Virginia colony along the Hudson river. But due to difficulties in the crossing and a navigation error the ship made landfall at Cape Cod. Many passengers on the ship realised that the letters patent from the Company of Merchant Adventurers of London did not apply to the region where the settlers had landed, and some passengers insisted this meant that they were free to do as they wished. Fearing that this would make any settlement ungovernable, the passengers on the ship committed to 'covenant and combine ourselves together into a civil Body Politik, for our better Ordering and Preservation' and promised 'all due Submission and Obedience' to 'such just and equal Laws, Ordinances, Acts, Constitutions, and Officers, from time to time, as shall be thought most meet and convenient for the general Good of 
the Colony'. ${ }^{3}$ Together with the Declaration of Independence and the United States Constitution the Mayflower Compact is often seen as one of the three foundational constitutional documents of the US. It constituted the Mayflower settlers as a body politic, created a basic version of rule of law in the new colony, and enshrined the principle of democratic rule in which laws would be passed by a vote of the colonists and the governor of the colony would be elected by its members. While there was no language of rights in the Mayflower Compact, the document did contain two of the other three pillars of global constitutionalism - democracy and the rule of law.

The other two, lesser-known agreements also established and secured the settlement. The first were the legal agreements between the settlers and the Plymouth Company - a joint stock corporation established by King James to settle the area along the east coast of America North of the 40th parallel. While the pilgrims' motivation for emigrating to America was to found a new community where they could practise their religion without persecution, the motivation of the investors in the Plymouth Colony was entirely commercial. Letters patents were granted to settlers which gave them title to land in exchange for providing goods to the company normally for a period of seven years. The primary interest at this point in time were the fur trade, timber and cod. All of which the colonists were expected to acquire and ship back to England in exchange for eventually receiving title to the land.

The third agreement was between the settlers and the Wampanoag nation negotiated by their Sachem Massasoit and a bilingual member of Patuxet nation Squanto 4 and the Plymouth Colony Governor John Carver. The agreement was as follows:

1. That neither he nor any of his should injure or do harm to any of our people.

2. And if any of his did hurt any of ours, he should send the offender, that we might punish him.

3. That if any of our tools were taken away when our people were at work, he should cause them to be restored, and if ours did any harm to any of his, we would do the like to him.

3 Philbrick (n 2) 40-2.

${ }^{4}$ Squanto had been kidnapped by English explorers in 1614 and taken back to Europe as a slave. Over the next five years he had lived in Spain and England and had learned European languages. In 1619 he returned to the Americas acting as a guide for English explorers but managed to escape when the English ship was attacked by the Massasoit. Because of his knowledge of English and European culture he was able to act as a negotiator on behalf of the Massasoit in their discussions with the Plymouth colonists. 
4. If any did unjustly war against him, we would aid him; if any did war against us, he should aid us.

5. He should send to his neighbor confederates, to certify them of this, that they might not wrong us, but might be likewise comprised in the conditions of peace.

6. That when their men came to us, they should leave their bows and arrows behind them, as we should do our pieces when we came to them. ${ }^{5}$

The agreement was just as significant as the Mayflower Compact as it established peaceful relations between Wampanoag and the Plymouth Colony on the basis of mutual protection of life and property, collective security, and a basic immigration agreement between the two communities. Unfortunately, as the number of settlers in the Plymouth Colony grew, the agreement between the Wampanoag and Pilgrims would break down, leading eventually to King Philip's War in 1675-1676 that killed 40 per cent of the population of the Wampanoag nation, and the enslavement of the remaining Indigenous population. ${ }^{6}$

From a global constitutionalist perspective, the story of the Mayflower highlights both the promise and the precarity of transnational law. The Mayflower enterprise was only possible because of the three bedrock agreements: the Mayflower Compact to establish democracy and the rule of law amongst the settlers; the treaty with the Wampanoag to provide the trade and security that enabled the settlers to survive their first years in the Americas; and the contract between the settlers and the investors back in England to provide the initial funding for the expedition in exchange for the indentured labour and resource expropriation of the Americas by the colonists. Over the next 55 years the avarice of the commercial motivations for the settlement and the conflict that resulted as more and more European settlers displaced the Indigenous populations led to a breakdown of the constitutional order in the New World, to war, and ultimately to genocide.

\section{Dismantling global constitutionalism's colonial legacy}

To properly understand the significance of the Mayflower voyage for global constitutionalism is to begin the process of decolonising how global constitutionalism is practised and studied. We follow Rutazibwa and Shilliam in defining decolonisation as a 'heuristic device that sensitises the thinker to the multiple, contending and overlapping legacies of colonial rule and 
imperial administration that inform contemporary global politics'. ${ }^{7}$ Building upon last year's editorial calling for greater diversity in the study of global constitutionalism, this year the editors would like to use the connection between the Mayflower anniversary and the relocation of the journal to Southampton to call upon our readers to reflect upon how colonial and imperial order have shaped democracy, the rule of law, and human rights across the global normative order.

From a substantive perspective, as editors of Global Constitutionalism (GlobCon) we are conscious of the fact that the most common frames in the discipline have been the beneficiaries and vehicles of a colonialist legacy. GlobCon therefore seeks to emphasise the presence and validity of alternative frames. Dominant 'Western' understandings of the modern liberal constitutional order and rule of law have been transmitted along with colonial political power, and used to justify the prevalence and continued advancement of these ideas. ${ }^{8}$ There have been moments where the relationship between colonialist impulses and claims to normative legitimacy have been explicit. One cogent claim available to the 'global West' during the Cold War was that its political structures were legitimised by constitutional and rule-of-law norms which subsequently served as vehicles for advancing hegemonic ideology. Likewise, the second war in Iraq was legitimated in part by claims regarding the constitutional and legal features of America, and the assertion that these fundamental norms would form the basis for a new Iraqi government. These declarations of moral standing form a striking parallel with the claims to spiritual rectitude that motivated the Puritans and provided them with internal legitimation in their dealing with the inhabitants of the New World.

Beyond identifying and analysing the ways in which constitutional ideology has depended upon colonialism for its ascendance, GlobCon aims to de-colonise by providing an academic forum for other forms of legal and political ordering. We have already taken initial steps towards this goal with an upcoming symposium on global constitutionalism in Asia and the Pacific. Considering the decolonisation of the journal, however, will require further work of this type, and a sustained dedication to considering alternative forms of political and legal organisation on their own terms. Such a project will require not merely acknowledging how dominant ideas in global constitutionalism have had a wide influence, but rather a willingness to consider systems from outside the colonial tradition on their

7 OU Rutazibwa and R Shilliam (eds), 'Postcolonial Politics: An Introduction' in Routledge Handbook of Postcolonial Politics (Routledge, Abingdon, 2018) 1.

${ }^{8} \mathrm{~J}$ Tully, 'The Unfreedom of the Moderns in Comparison to Their Ideals of Constitutional Democracy' 65(2) Modern Law Review (2002) 204. 
own terms. In this regard, we will need to stand in direct opposition to the proselytising and dogmatic attitude so frequently adopted by the West (and not the least by the Mayflower colonists themselves).

Following on from our editorial last year, ${ }^{9}$ we further call upon scholars of global constitutionalism to dedicate themselves to decolonising our field. This will require researchers take a pluralist view towards the rule of law, human rights, and democratic theory. It will also require a commitment to analysing the colonial legacy in constitutional formation, the contemporary rights regime, and international public law, from both theoretical and historical perspectives. Finally, it can only occur if forums for scholarship are open to opportunities for persons from formerly colonised spaces to critique the colonial legacy and robustly express new ideas in and ideals of global constitutionalism. Through facilitating these efforts, GlobCon hopes to be a part of this process of critically reviewing, and in time transforming, the colonial legacy.

9 A Wiener, JL Dunoff, J Havercroft, M Kumm and K Kovacs, 'Global Constitutionalism as Agora: Interdisciplinary Encounters, Cultural Recognition and Global Diversity’ (2019) 8(1) Global Constitutionalism 1. 